\title{
Monitoring the Health Status of Trees in Maksimir Forest Park Using Remote Sensing Methods
}

\author{
Franka Zagoranski ${ }^{1}$, Renata Pernar ${ }^{2}$, Ante Seletković ${ }^{2}$, Mario Ančić ${ }^{2}$, Jelena Kolić ${ }^{2 *}$
}

(1) Ravenska 28, HR-10000 Zagreb, Croatia; (2) University of Zagreb, Faculty of Forestry, Department of Forest Inventory and Management, Svetošimunska 25, HR-10000 Zagreb, Croatia

* Correspondence: e-mail: jkolic@sumfak.hr
Citation: ZAGORANSKI F, PERNAR R, SELETKOVIĆ A, ANČIĆ M, KOLIĆ J 2018 Monitoring the Health Status of Trees in Maksimir Forest Park Using Remote Sensing Methods. South-east Eur for 9 (1): 81-87. DOI: https://doi.org/10.15177/ seefor.18-08

Received: 17 Apr 2018; Revised: 8 Jun 2018; Accepted: 15 Jun 2018; Published online: ?? Jun 2018

\begin{abstract}
Background and Purpose: In Zagreb, the forests have assumed the characteristics of forest parks, of which the most famous and the most visited is Maksimir Park. The health condition of many trees has deteriorated due to environmental changes and the forest's age. The tree health status can be monitored by direct observation in the field using the terrestrial method, or by remote sensing methods. Recent advances in technology have made it possible to use highresolution satellite imagery to monitor the damage.

Materials and Methods: In order to estimate the health status of trees, the research area - Maksimir Forest Park - was visually interpreted by means of the WorldView 2 (WV2) satellite image, color composite $(8,5,3)$. Such color composite was also used to delineate the strata. After delineation, a systematic sample of $25 \times 25 \mathrm{~m}$ was laid over the stratum to help interpret the tree health status. Differences in tree damage were observed by comparing the WV2 images and other satellite images (Google Earth images from 2014 and 2016) recorded at different points in time. Field research was then conducted in order to inventory the current situation.

Results: The main results of the research in Maksimir Forest Park include the calculation of damage indicators by tree species, as well as thematic maps with the spatial distribution of the mean damage (SO) and damage index (IO) for those tree species which are most represented in a particular stratum. Mean and significant damage of the most represented tree species and overall is also presented spatially in the form of thematic maps. A comparison of the results of WV2 satellite imagery and satellite images taken from Google Earth denoted a change in the tree health status, which confirms that satellite imagery can serve to inventory and track the condition in an area over a number of years. Field investigations and the assessment of tree health status confirmed the results obtained by satellite imagery interpretation. Conclusions: Since quality forest monitoring is based on systematic collection of forest data in any area or at any point in time, the obtained results not only represent the current health status, but also provide a basis for monitoring and predicting the future conditions.
\end{abstract}

Keywords: WorldView 2 satellite image, visual interpretation, monitoring, the health status of trees, urban forest, GIS

\section{INTRODUCTION}

With the rapid development and expansion of urban areas, as well as with a growing share of the population living in such areas, the preservation and protection of green spaces is increasingly gaining in importance. Zagreb is among the very few European capitals with well preserved natural forests which are incorporated into the urban tissue of the city itself [1]. Such forests play an exceptional role in the life of a society which is being intensively urbanized [2]. In particular, this applies to recreational activities [3-5], the reduction of air pollution [6, 7], microclimate regulation [8] and erosion reduction [9]. In Zagreb, forests have assumed the characteristics of forest parks, of which the most famous and the most visited is Maksimir Park. In addition to being a widely used recreational area, it is also an ecological stronghold that offers a variety of benefits. It was the first public park in southeastern Europe and one of the first such parks in the world [10]. Since its foundation the 
forest has undergone numerous changes, but it still remains a unique set of natural forest elements. In order to retain the stability of the forest ecosystem it is necessary to perform various regeneration and tending operations and maintain the forest in an optimal condition so that it continues to provide all of its non-market functions. The health condition of many trees has deteriorated due to environmental changes and the forest's age. The tree health status can be monitored by direct observation in the field using the terrestrial method [11, 12], or by remote sensing methods, most commonly by interpreting color infrared (CIR) aerial images [13, 14]. Recent advances in technology have made it possible to use high-resolution satellite imagery to monitor the damage. Remote sensing methodology reduces the amount of necessary field work and cuts down on expenditures [15]. This paper shows how visual interpretation of the health status of individual trees is performed on the WorldView 2 satellite image.

\section{MATERIALS AND METHODS}

The survey was conducted in the Maksimir Forest Park on an area of 168.40 hectares. In order to estimate the health status of trees, the research area - Maksimir Forest Park - was visually interpreted by means of the WorldView 2 (WV2) satellite image, color composite $(8,5,3)$. The combination of bands 8,5 , 3 was chosen so as to clearly distinguish tree species, vegetation types, physiological conditions, developmental stages etc. Damage indicators were determined with the color composite structured in this manner. Such color composite was also used to delineate the strata (Figure 1). The strata were differentiated using visible differences in image details, such as tree species, mixture ratio, stand closure, crown size, the degree of damage etc. The stage of tree damage was assessed according to a determined percentage of assimilation organ absence (leaves), the percentage of yellow leaves and the percentage of branch decline. After delineation, a systematic sample of $25 \times 25 \mathrm{~m}$ was laid over the stratum to help interpret the tree health status (Figure 2). At each point of a grid (2982 points), 2 nearest trees (crowns) were estimated and damage indicators (damage - 0 , mean damage - SO, damage index - 10 , mean damage $-\mathrm{SO}_{1}$ ) [16] were calculated for individual tree species, and for all the interpreted species together.

The interpretation results were used to construct thematic maps of the spatial distribution of damage [17]. The thematic maps of the spatial distribution of damage have made it possible to distinguish the most damaged strata in relation to certain tree species. Satellite images available on Google Earth were also used to monitor the health status of trees in Maksimir forest area. Differences in tree damage were observed by comparing the WV2 images and other satellite images (Google Earth) recorded at different points in time (from 2014 and 2016). This way it was possible to identify all the changes that occurred during a certain period of time. Areas with more severe tree damage were determined by using thematic maps and the selected strata and by comparing the satellite images. Stratum 28 containing the largest number of damaged oak trees was delineated in the study area. The changes observed on the trees in the images are marked with circles (Figure 3, 4, 5). Field research was then conducted in order to inventory the current situation.

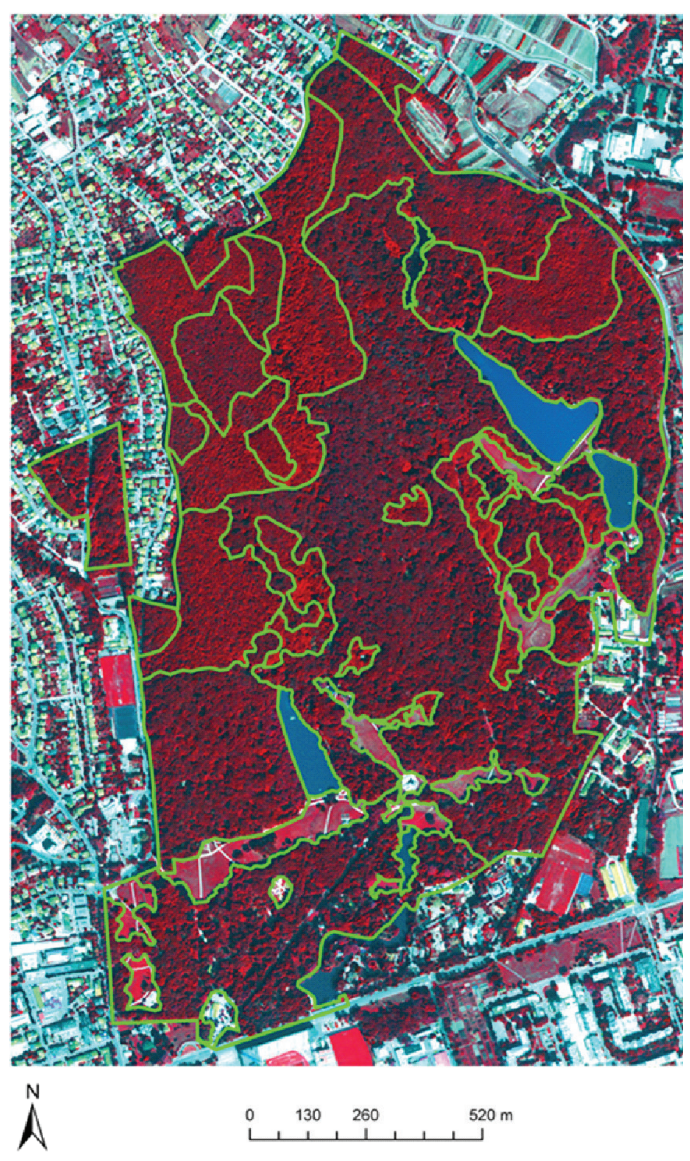

FIGURE 1. The research area - Maksimir Forest Park (with delineated strata).

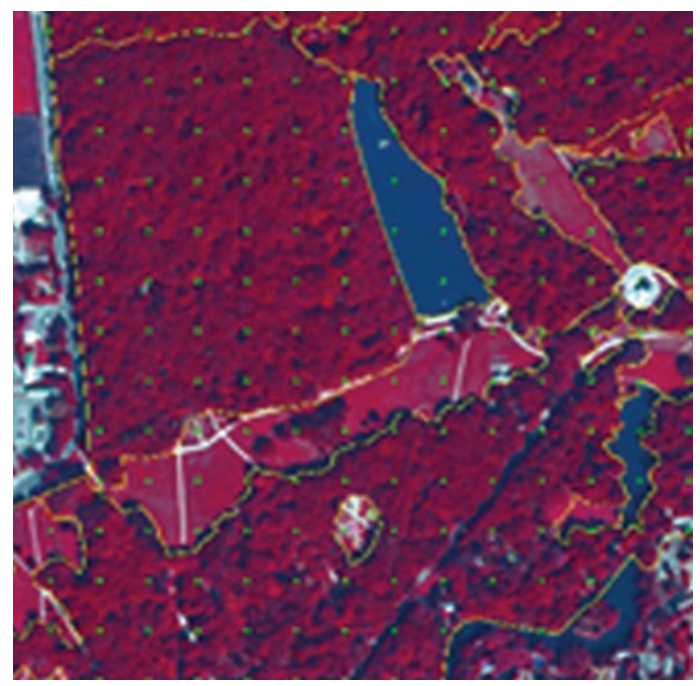

FIGURE 2. The clip of color composite $(8,5,3)$ with a systematic sample. 

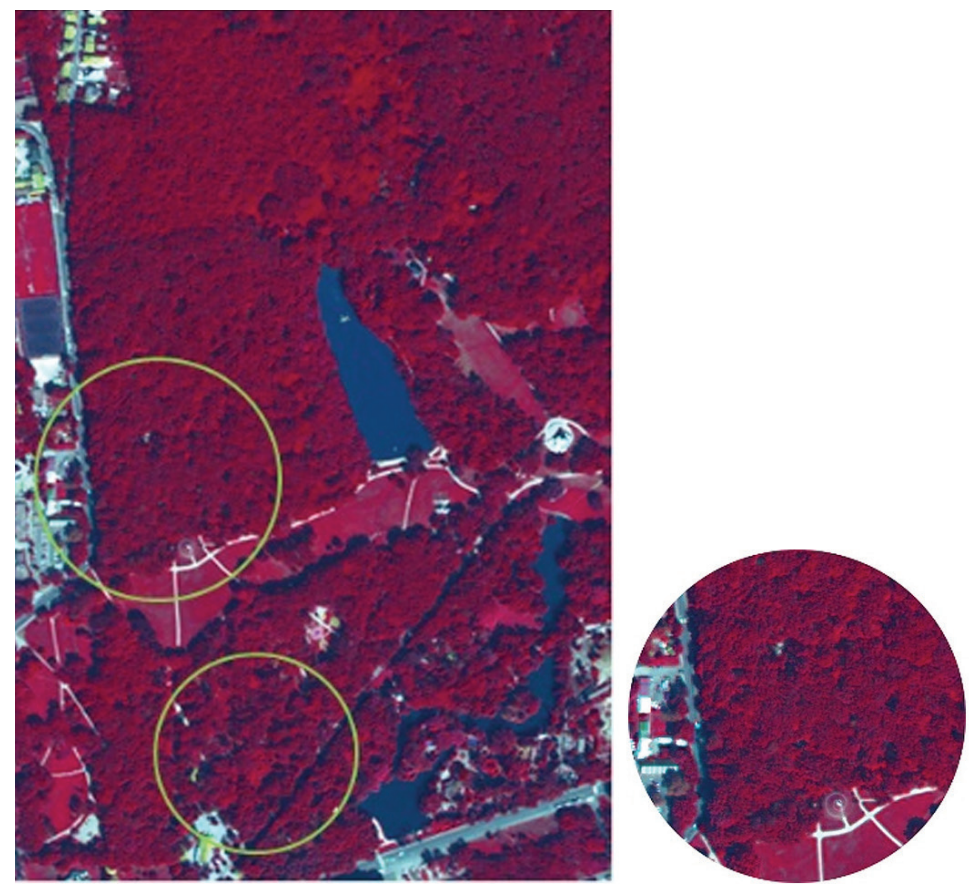

FIGURE 3. WorldView 2 satellite image from 2011 with marked areas of significant damage to oak and a fragment from the Stratum 28.
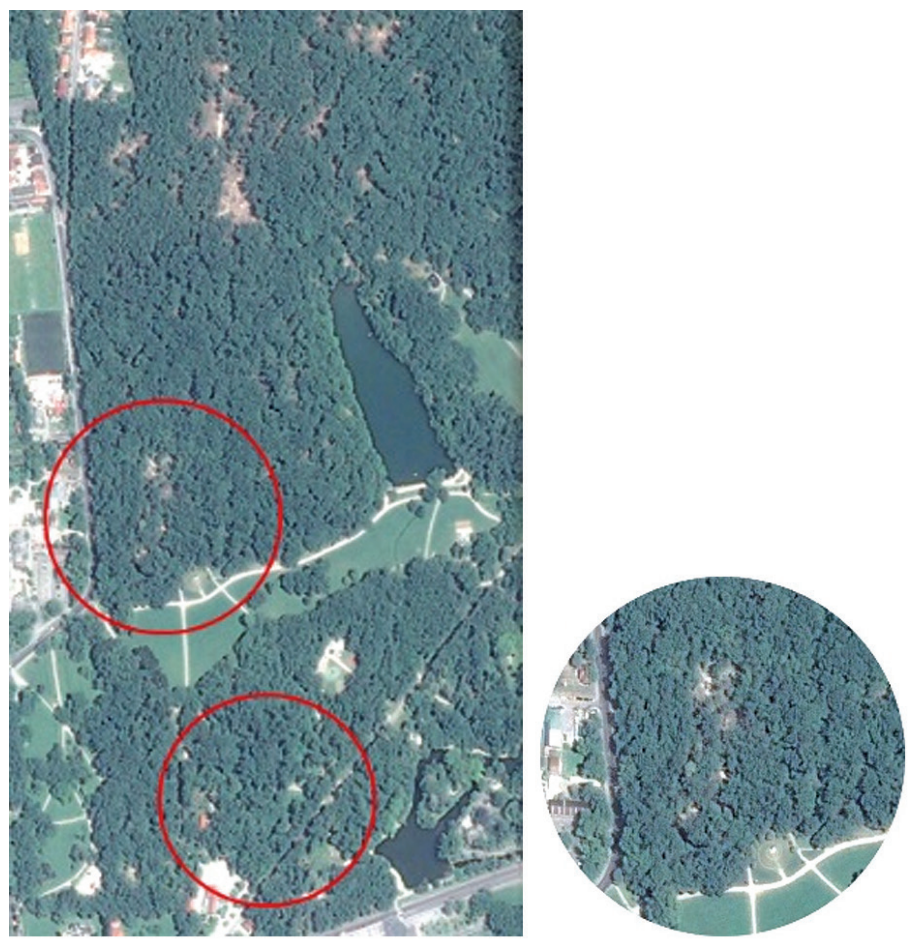

FIGURE 4. Satellite image (Google Earth) from 2014 with marked areas of significant oak damage and a fragment from Stratum 28. 

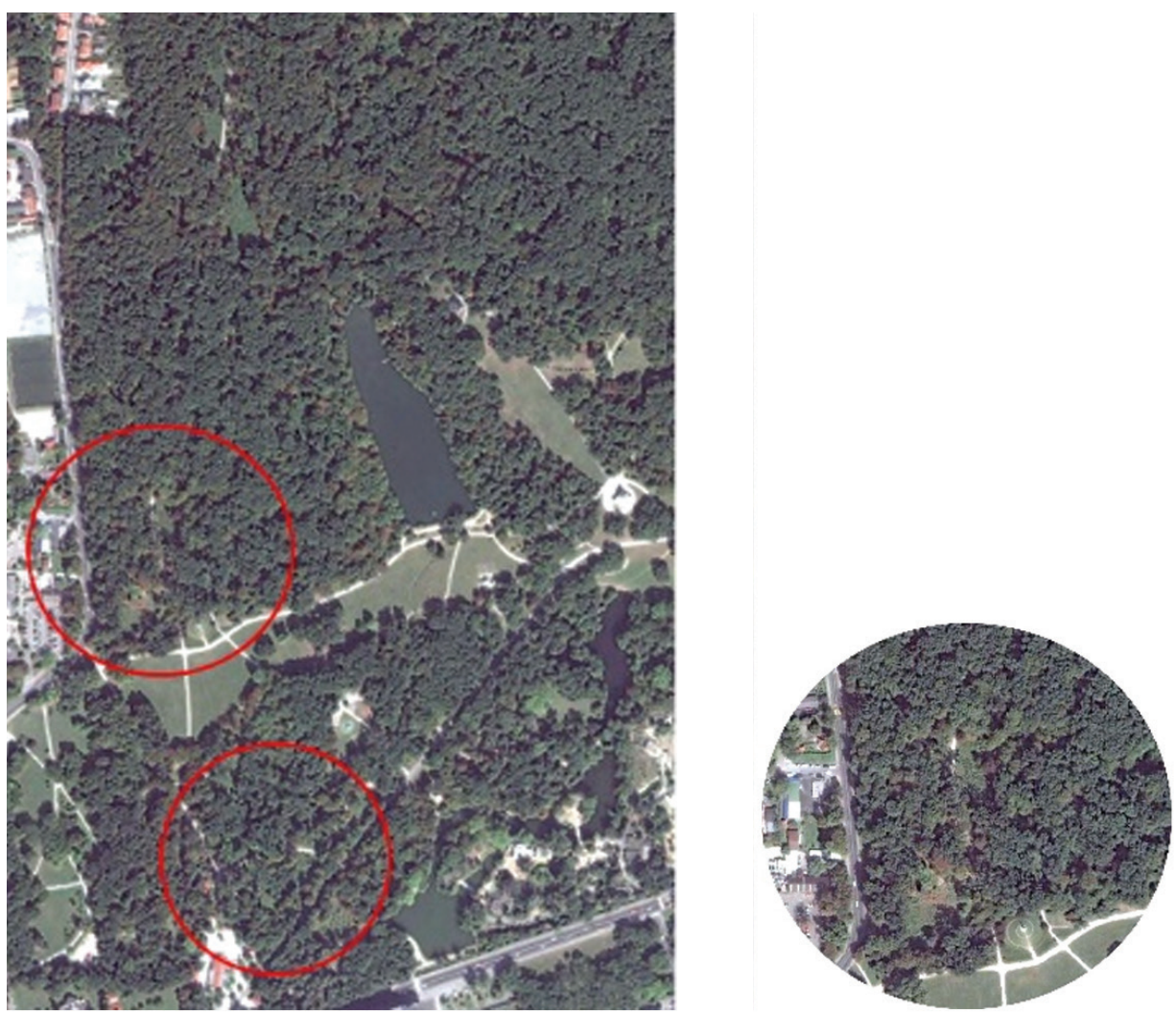

FIGURE 5. Satellite image (Google Earth) from 2016 with marked areas of significant oak damage and Stratum 28 fragment.

In addition to surveying the selected areas, the position was identified in the field with a GPS device. Photodocumentation was recorded for subsequent comparison with the results obtained by the interpretation of the recording. The field survey consisted of 6 locations (Figure 6), which were marked as critical with regard to the damage and health condition of the observed oaks.

\section{RESULTS AND DISCUSSION}

The main results of the research in Maksimir Forest Park include the calculation of damage indicators by tree species, as well as thematic maps with the spatial distribution of the mean damage (SO) and damage index (IO) for those tree species that are most represented in a particular stratum. Data were also obtained for the surfaces of individual strata. A total of 5,064 individual trees were photo-interpreted in the systematic $25 \times 25 \mathrm{~m}$ sample $(2982$ points) in the recorded area. The most represented tree species in the sample was oak (4,403 trees), followed by hornbeam (404 trees) and black locust (76 trees). In the entire recorded area, the highest mean damage (SO) and the highest damage index (IO) were recorded for oak. Taking into account all the interpreted trees in the recorded area, mean damage can be estimated at $39.76 \%$, and significant damage (IO) at $70.69 \%$ (Table 1). In the sample of $70.69 \%$ of the trees classified as 2.1 and higher, mean damage $\left(\mathrm{SO}_{1}\right)$ amounts to $50.16 \%$ and can be classified as 2.2 degree of damage. Hence, the stands in Maksimir area can be assigned to the category of moderately to severely damaged stands. Mean and significant damage of the most represented tree species (oak) and overall is also presented spatially in the form of thematic maps (Figure 7).

Validation of the tree condition in the field produced the results that represent the current health status of the investigated area. Field investigation, conducted in May 2017, comprised areas of significant oak damage in Maksimir Forest Park. Photo-documentation made on this occasion showed that in Location 1 the majority of badly damaged trees were removed and the area was restored by planting seedlings. Area 1 is located in Stratum 28, in which interpretation comprised the largest number of damaged oak trees. In Area 3, located in Stratum 31, the damaged and diseased trees were replaced with new, young trees (Figure 8).

This can be confirmed by the available literature. Namely, Glavaš [18] states that about 1,000 trees in Maksimir Forest Park were destroyed by a storm. The restoration of the affected areas began in 2014, when new 




FIGURE 6. Field investigation in digital orthophoto (GPS tracking route).

trees were planted [19]. A comparison of the results of WV2 satellite imagery and satellite images taken from Google Earth (from 2014 and 2016) denoted a change in the tree health status, which confirms that satellite imagery can serve to inventory and track the condition in an area over a number of years. Field investigations and the assessment of tree health status confirmed the results obtained by satellite imagery interpretation, but also indicated that the future condition of stands can be predicted on the basis of the images $[16,20]$. Images taken in different years are a good starting point for predicting the condition in the field for a certain period, which is a prerequisite for good planning.
TABLE 1. Damage indicators by tree species (O - damage; 10 - damage index (significant damage); SO - mean damage; $\mathrm{SO}_{1}$ mean damage of significantly damaged trees).

\begin{tabular}{|c|c|c|c|c|}
\hline \multirow{3}{*}{ Tree species } & \multicolumn{4}{|c|}{ Damage indicators } \\
\hline & 0 & 10 & so & $\mathrm{SO}_{1}$ \\
\hline & \multicolumn{4}{|c|}{$\%$} \\
\hline Oak sp. & 99.68 & 79.33 & 43.58 & 50.42 \\
\hline Common Hornbeam & 37.62 & 0.00 & 9.70 & \\
\hline Black locust & 85.53 & 51.32 & 24.54 & 34.74 \\
\hline Common beech & 48.48 & 0.00 & 11.06 & \\
\hline Spruce sp. & 80.65 & 41.94 & 32.82 & 59.81 \\
\hline Pine sp. & 100.00 & 64.71 & 31.84 & 39.66 \\
\hline Other* & 56.63 & 15.66 & 14.43 & 32.50 \\
\hline Total & 93.36 & 70.69 & 39.76 & 50.16 \\
\hline
\end{tabular}

*(maple, fruit trees, lime tree, alder, poplar...)

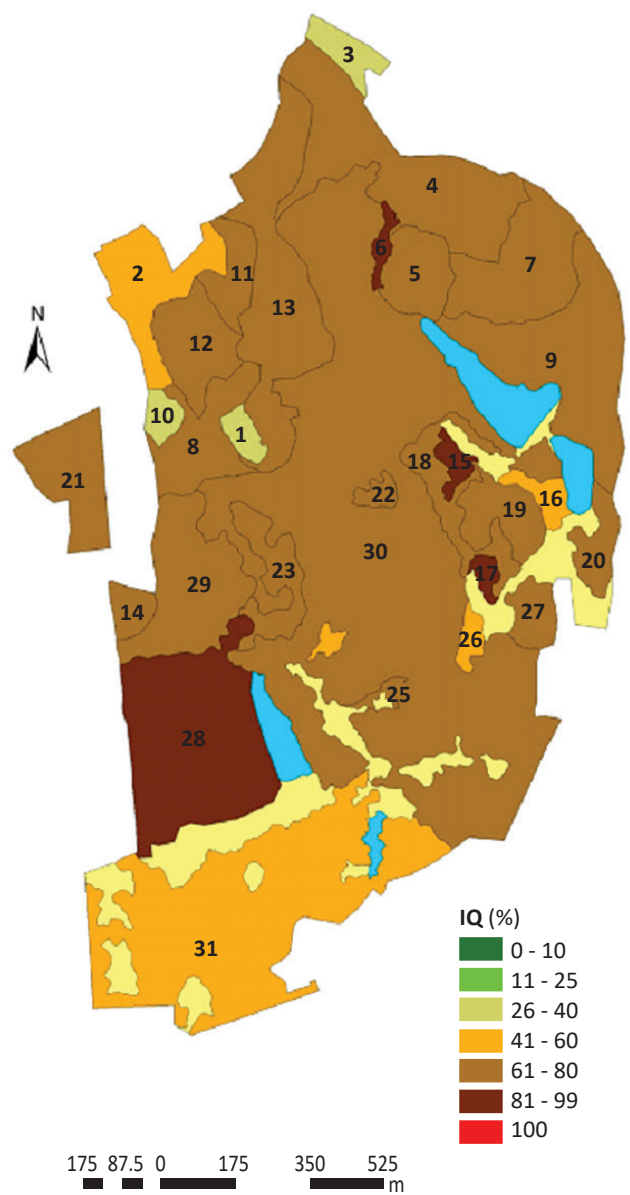

FIGURE 7. Total Damage Index for all tree species (IO significant damage) - Maksimir Forest Park. 


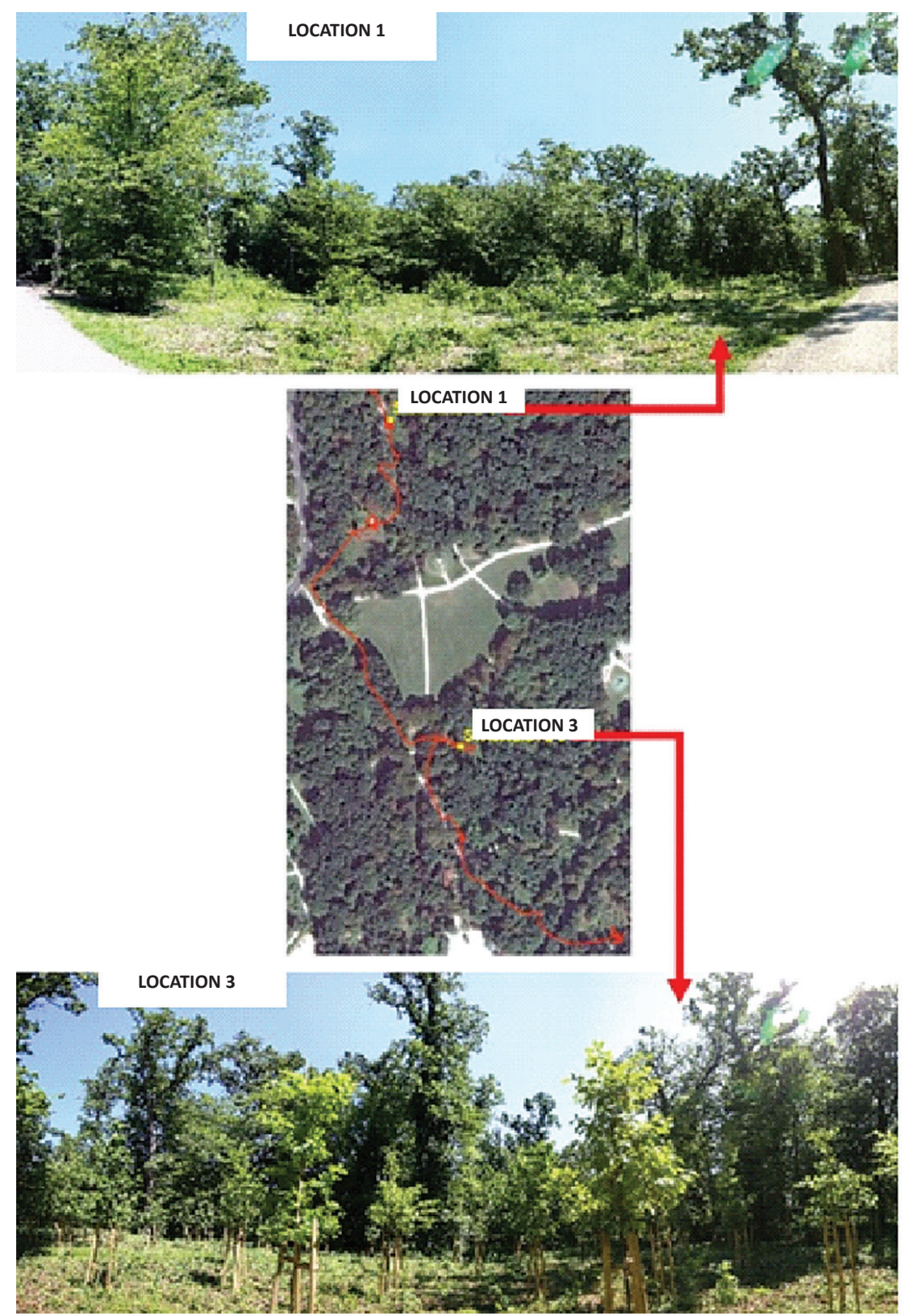

FIGURE 8. Locations 1 and 3.

\section{CONCLUSIONS}

A survey conducted by means of the WorldView 2 satellite image showed the current health status of the most common tree species in Maksimir Forest Park. Monitoring tree health by interpreting satellite images enables rapid and economic data acquisition. Since quality forest monitoring is based on a systematic collection of forest data in an area or at any point in time, the obtained results not only represent the current health status, but also provide a basis for monitoring and predicting the future conditions. In urban environment, it is of particular importance to make timely predictions of the changes in tree health status so that diseased trees can be removed and replaced with new ones. 


\section{REFERENCES}

1. MATIĆ S 2010 Njega, održavanje i obnova park-šuma kao temeljni preduvjet njihove vječnosti. In: Matić S, Anić I (eds) Park-šume grada Zagreba. . Academy of Forestry Sciences, Zagreb, Croatia,. pp 83-94

2. STANIĆ S, BUZOV I 2014 Značenje zelenih prostora u životu grada. Godišnjak Titius 6-7 (6-7): 137-153

3. TYRVÄINEN L, MIETTINEN A 2000 Property prices and urban forest amenities. J Environ Econ Manag 39 (2): 205223. DOI: https://doi.org/10.1006/jeem.1999.1097

4. TYRVÄINEN L 2001 Economic valuation of urban forest benefits in Finland. J Environ Manage 62 (1): 75-92. DOI: https://doi.org/10.1006/jema.2001.0421

5. JIM CY, CHEN WY 2006 Recreation-amenity use and contingent valuation of urban greenspaces in Guangzhou. Landscape Urban Plan 75 (1): 81-96. DOI: https://doi. org/10.1016/i.landurbplan.2004.08.008

6. BECKETT KP, FREER-SMITH PH, TAYLOR G 1998 Urban woodlands: their role in reducing the effects of particulate pollution. Environ Polluti 99 (3): 347-360. DOI: https://doi. org/10.1016/S0269-7491(98)00016-5

7. AKBARI H, POMERANTZ M, TAHA H 2001 Cool Surfaces and Shade Trees to Reduce Energy Use and Improve Air Quality in Urban Areas. Sol Energy 70 (3): 295-310. DOI: https:// doi.org/10.1016/S0038-092X(00)00089-X

8. AKBARI H 2002 Shade trees reduce building energy use and $\mathrm{CO}_{2}$ emissions from power plants. Environ Pollut 116 (1): 119-126. DOI: https://doi.org/10.1016/S02697491(01)00264-0

9. MCPHERSON EG, SIMPSON JR 2003 Potential energy savings in buildings by an urban tree planting programme in California. Urban For Urban Gree 2 (2): 73-86. DOI: https://doi.org/10.1078/1618-8667-00025

10. BOJANIĆ OBAD ŠĆITAROCI B, OBAD ŠĆITAROCI M 2004 Gradski perivoji Hrvatske u 19. stoljeću (Public Parks of Croatian Towns in 19th Century in European Context). Faculty of Architecture, Zagreb, Croatia, pp 124-133
11. PRPIĆ B, KOMLENOVIĆ N, SELETKOVIĆ Z 1988 Propadanje šuma u SR Hrvatskoj (Dieback of Forests in Croatia). Šumar list 113 (5-6): 195-216

12. POTOČIĆ N, SELETKOVIĆ I 2011 Osutost šumskog drveća u Hrvatskoj u razdoblju od 2006. do 2009. godine. Šumar list 135 (13): 149-158

13. KALAFADŽIĆ Z, KUŠAN V 1990 Definiranje stupnja oštećenosti šumskog drveća i sastojina. Šumar list 114 (1112): 517-526

14. PERNAR R 1994 Method and reliability of assessing damage to pedunculate oak (Quercus robur L.) using colour infrared aerial photographs. Glasnik za šumske pokuse 31: 1-34

15. PERNAR R, ŠELENDIĆ D 2006 Prilog povećanju interpretabilnosti aerosnimaka i satelitskih snimaka za potrebe uređivanja šuma. Glasnik za šumske pokuse 5: 467-477

16. KOLIĆ J, PERNAR R, SELETKOVIĆ A, ANČIĆ M 2015 The Importance of CIR Aerial Imagery in Inventory, Monitoring and Predicting Forest Condition. South-east Eur for 6 (2): 191-200. DOI: https://doi.org/10.15177/seefor.15-18

17. PERNAR R, SELETKOVIĆ A, ANČIĆ M, KOLIĆ J 2012 Procjena zdravstvenog, stanja stabala G.J. Park šuma Grada Zagreba metodama DI. University of Zagreb, Faculty of Forestry, 123 $\mathrm{p}$

18. GLAVAŠ M 2013 Olujno nevrijeme mobiliziralo UŠP Zagreb, Karlovac i Delnice. Hrvatske šume 204: 14-16

19. JAVNA USTANOVA MAKSIMIR 2015 Godišnji program zaštite, održavanja, očuvanja, promicanja i korištenja zaštićenih područja Grada Zagreba. Javna ustanova Maksimir, Zagreb, Croatia 23 p. URL: http://www.parkmaksimir.hr/Maksimir media/Program rada 2015.pdf (20 February 2018)

20. GAŠPAROVIĆ M, MEDAK D, MILER M 2017 Geospatial monitoring of green infrastructure - case study Zagreb, Croatia. In: Conference Proceedings of 17th International Multidisciplinary Scientific Geoconference SGEM 201717 (33): 569-576. DOI: https://doi.org/10.5593/ sgem $2017 \mathrm{H} / 33$ 